\title{
Social Security Policy
}

\section{Giuliano Bonoli}

\subsection{Main Objectives and Policy Instruments}

As in other European countries, the social security system in Switzerland has a range of objectives ${ }^{1}$. These reflect the chronological and gradual development of the system. The system aims at providing a guaranteed minimum income for the entire resident population. The first schemes introduced at the national level, old age pensions in 1948 and disability insurance in 1960, clearly had this objective. They tried to achieve it by providing at least subsistence-level benefits to virtually all residents.

During the 1960s and early 1970s, the rise of the middle classes prompted the adoption of a more ambitious objective: an income guarantee aiming to give the recipients of benefits a standard of living close to the one they would have had-had they not been disabled, become unemployed, and so forth. Existing programmes were revised accordingly, and a compulsory second pillar of old age pension provision was introduced. In disability insurance, a system of benefit increases was introduced, which

${ }^{1}$ This chapter is based on research carried out in the context of the European Social Protection Network. It draws heavily on Bonoli and Trein (2017).

G. Bonoli $(\bowtie)$

IDHEAP, University of Lausanne, Lausanne, Switzerland e-mail: giuliano.bonoli@unil.ch

(C) The Author(s) 2019

A. Ladner et al. (eds.), Swiss Public Administration, Governance and Public Management, https://doi.org/10.1007/978-3-319-92381-9_18 
was meant to reflect the wage increases workers typically experience during their careers. The new schemes, including unemployment insurance (introduced in 1978), had the goal of maintaining income levels from the start.

Towards the mid-1990s, with the rise in mass unemployment and permanent exclusion from the labour market for many, a new objective was added: activation. Over the last 20 years, the social security system has been gradually transformed, and the primary objective of all the relevant schemes is explicit to put "clients" back into the labour market. Several instruments are used to that effect: rehabilitation services for the disabled, active labour market policies for the long-term unemployed, vocational training, and wage subsidies.

In other words, over time, the Swiss welfare state has gone from being the provider of a minimum income to all to becoming an activation machine. Of course, this transformation concerns programmes providing coverage to working-age people. The old age pension system has not been affected by the "activation turn", also because Switzerland never really developed large-scale early retirement schemes.

With regard to the specific institutional architecture of the social security system for working-age individuals, there are three main schemes. First, Switzerland has a federal unemployment insurance programme. Contribution rates and benefit levels, as well as most other features, are set by the federal parliament, though the implementation is a cantonal responsibility. While cantons must implement federal law and must organize a public employment service (PES), they have a large degree of autonomy in many areas, including activation, coordination with other schemes, and managing their own PES. The federal government monitors the implementation and the performance of the cantonal PES, using somewhat controversial indicators and a benchmarking system.

Disability insurance is also a federal scheme implemented by the cantons. Such insurance provides earnings replacement benefits for individuals who cannot work because of a long-term or permanent medical impairment, but it also provides substantial rehabilitation and other activation-related services. In this case, too, cantons are relatively free with regard to how they choose to implement the programme, again within the terms and conditions set by federal law.

Finally, social assistance is entirely regulated and financed at the cantonal level. Federal-level involvement in social assistance is limited to an 
article in the federal constitution which entitles every resident to a minimum subsistence income and de facto forces cantons to run social assistance schemes (Swiss Constitution, Art. 115). As cantons give municipalities leeway, there is some variety in the approaches adopted in the different parts of the country. We lack a precise view of what actually goes on in terms of benefits and services across the 26 cantons and about 2200 municipalities that make up Switzerland.

Against the background of this high level of institutional fragmentation, a non-governmental body, the Swiss Conference for Social Welfare (CSIAS/SKOS), plays a very important role. CSIAS/SKOS is a private association with representatives of cantonal and municipal social services as well as from the main anti-poverty organizations such as Caritas. It has about 1000 individual and collective members. CSIAS/SKOS issues guidelines concerning benefit levels as well as the design and implementation of social assistance; its guidelines encompass several hundred pages of text (SKOS 2015). These guidelines are very precise and most cantons use them in defining social assistance rules and practices; they help reduce what would otherwise be a very high degree of variation across cantons and municipalities in social assistance practices and policy.

For the non-working-age population, Switzerland has developed an old age pension system based on three pillars. The first pillar covers the basic needs of retirees. It is moderately earnings-related and includes a meanstested pension supplement (Ergänzungsleitungen/Prestations complémentaires, EL-PC). The second pillar tries to ensure that retirees enjoy a standard of living close to the one they experienced while last employed and consists of mandatory occupational pensions for salaried employees. The third pillar makes it possible to tailor pension coverage to individual needs through non-compulsory personal pension payments which receive favourable tax treatment.

The first pillar provides universal coverage and is fairly redistributive. There is no contribution ceiling, but the amount of the benefit can vary between a floor and a ceiling twice as high as the floor. In 2018, the limits were set at CHF 1175 ( $€$ 950) and CHF 2350 (€1900) per month, respectively, corresponding to approximately $20 \%$ and $40 \%$ of the average wage. Benefits are adjusted every two years using a "mixed index" derived from the arithmetic average of inflation and wage increases. A full pension is paid at age 64 for women and 65 for men. 
The second pillar, occupational pensions, became compulsory in 1985 for all employees earning at least twice the minimum "first pillar" pension (Bonoli 2007; Leimgruber 2008). Coverage is near-universal among full-time employees, but some part-time and temporary workers are excluded. In fact, second pillar pensions are compulsory for workers earning more than 21,150 CHF per year (20,000 EUR). This threshold corresponds to about $30 \%$ of the average full-time wage. A full occupational pension is granted to employees who have contributed for 39 (women) or 40 (men) years. The law provides for a compulsory minimum level of provision (known as the Obligatorium) calculated on the basis of notional contributions. This gives existing pension funds a relatively high degree of autonomy over how to deliver and finance that minimum level of provision. It must be fully funded for private sector employers. Many pension funds, especially in the public sector, or those sponsored by large employers, offer better conditions than the Obligatorium (Bonoli and Gay-des-Combes 2003; Vontobel 2000). The occupational pension law also prescribes a government-set minimum nominal interest rate for second pillar pension funds covered by the Obligatorium. An important parameter defining second pillar pension benefits is the rate at which the accumulated capital is converted into an annuity (Umwandlungsatz/taux de conversion); that rate is set by law and currently stands at $6.8 \%$.

The third pillar consists of voluntary private individual pensions which are tax-favoured. Employees can deduct payment into a third pillar pension account of up to CHF 6768 ( $€ 5547$; figure for 2018) per year. The self-employed, who are not covered by compulsory occupational pensions, can deduct up to $20 \%$ of their earnings.

The Swiss multipillar pension scheme is seen as a rather successful example of a system that manages to address retirees' financial needs adequately without facing intractable financing problems. The division between the two main pillars, and the fact that the second pillar is fully funded, means that the ageing Swiss population will have less of an impact on the financing of pensions than countries in which the bulk of pension expenditure is financed on a pay-as-you-go basis. ${ }^{2}$

\footnotetext{
${ }^{2}$ In the literature on old age pensions, a distinction is made between pay-as-you-go schemes, in which current benefits are financed by current contributions, and funded schemes, in which current benefits are financed by past contribution. Funded systems are, in fact, compulsory savings schemes.
} 


\subsection{Main Actors and Structures}

The social security schemes presented above are large governmental programmes that rely on a range of actors and structures which are located at different levels of the Swiss federal state.

\subsubsection{Unemployment Insurance}

The federal State Secretariat for Economic Affairs is in charge of the unemployment insurance scheme. It oversees the implementation of unemployment insurance by the cantons, signs a performance agreement with them, and runs an indicator and benchmarking system. At the cantonal level, the key role is played by cantonal PESs, which are responsible for managing benefits and activation. They have substantial autonomy in implementation.

Intercantonal associations also play a large role, including the association of cantonal PES. This association coordinates the implementation of unemployment insurance across cantons and represents their common interests at the federal level. Regional placement offices are key actors in implementation. They belong to the canton's PES and provide monitoring and activation services for job seekers. They have some autonomy in implementation, but it is limited by the given cantonal PES. There are some 100 such regional placement offices in the country.

The unemployment compensation funds are additional, significant, actors. They can be either cantonal or branch based, and administer contributions and benefit payments. They have little autonomy and can be considered as purely administrative actors.

Finally, there are non-governmental organizations (mostly NGOs and more rarely, for-profit private companies) which provide the activation services needed by the PES.

\subsubsection{Disability Insurance}

The federal social insurance office is the key actor in disability insurance. It coordinates and oversees implementation by the cantons and, more importantly, takes the lead in proposing national legislation.

Implementation is the responsibility of cantonal disability insurance offices, which are responsible for managing both benefits and activation measures. They have substantial autonomy. 
As with unemployment insurance, intercantonal associations play a large role here. The most important one is arguably the intercantonal association of disability insurance agencies, which includes all cantonal disability insurance offices. It coordinates the implementation of unemployment insurance across cantons and represents their common interests at the federal level.

The regional medical services are another key actor; this provides the medical expertise needed in order to assess eligibility. There are ten regional medical services, each serving one or more cantonal disability offices.

In theory, they have little room for manoeuvre, as they have to strictly apply the law. In reality, medical assessments, especially of mental health, may fall into a grey area, giving a certain latitude to the regional medical services in how strictly they choose to implement the relevant laws. As with unemployment insurance, activation and rehabilitation services are provided mostly by non-state actors, including NGOs and for-profit private firms.

\subsubsection{Social Assistance}

Social assistance is a cantonal and municipal responsibility. As a result, there is no "social assistance office" or similar bureau at the federal level. As noted above, the only umbrella organization with a national scope is the Swiss Conference for Social Welfare, a private association.

Cantonal authorities (governments and parliaments), who are the most important actors, decide on cantonal social assistance laws. Given the absence of federal law in this area, they have substantial autonomy. Each canton has a social service, which is responsible for implementing social assistance laws, and regional or municipal social services deliver the benefits to clients. They are also in charge of the activation services, though their autonomy is limited by cantonal law. While big cities like Zurich, Basel, or Geneva can set up their own activation programmes (Duell et al. 2010 , p. 101), smaller cities and municipalities lack the resources and capacities to do the same.

In some cantons, one still finds social commissions. These are made up of citizens designated by the municipal executive. They make formal decisions concerning eligibility and access to activation services. This is a premodern institution with a strong social control function; it has survived mostly in the German-speaking part of the country but been largely 
abolished in French- and Italian-speaking cantons. As in other branches of the social security system, one finds NGOs, or more rarely, for-profit private companies, which provide activation services needed by social assistance offices.

\subsubsection{Old Age Pensions}

Old age pensions are a federal responsibility. They are overseen by the federal social insurance office. With regard to implementation, a distinction needs to be made between the first pillar, which is public, and the second pillar, which is company or branch based. The first pillar is carried out by some 100 "compensation funds". Some are public (each canton has one) but most are branch-based. Some very large employers such as Coop, a large supermarket chain, have their own. Compensation funds collect contributions and distribute benefits, but they are all interconnected and under the umbrella of a central compensation fund based in Geneva; it keeps the records of every insured person.

For the second pillar, the key actors are around 2000 occupational pension funds. Large companies generally have their own, while a number of branch-based funds exist which companies are free to join. Finally, most insurance companies and banks also provide second pillar coverage to employers who do not have their own fund.

\subsection{Policy Implementation and Outcomes}

Switzerland has long had a low unemployment rate and relatively few social problems. The Swiss labour market also has been doing relatively well during the last few years. These are all not necessarily a result of the welfare state.

The employment rate has remained above the European Union (EU) 2020 target of $75 \%$ throughout the period covered in Table 18.1. It is intriguing to see that between 2010-2011 and 2014 both the employment and the unemployment rates increase. This may reflect an increasing level of competition in the labour market.

Against the background of this overall good labour market performance, some groups are experiencing more difficulties, in particular younger workers who lack a completed vocational or academic education. As Table 18.2 shows, the unemployment rate for the 15-24 age group is considerably higher than the general one. 
Table 18.1 Key labour market indicators for the working-age (20-64) population

\begin{tabular}{lrrrrrr}
\hline & 2010 & 2011 & 2012 & 2013 & 2014 & 2015 \\
\hline Employment rate & 81.1 & 81.8 & 82.0 & 82.1 & 82.3 & 82.8 \\
Unemployment rate & 4.2 & 3.8 & 3.9 & 4.2 & 4.5 & 4.5 \\
Female employment rate & 74.6 & 75.4 & 76.0 & 76.6 & 77.4 & 78.2 \\
\hline
\end{tabular}

Source: Employment rates: Eurostat, unemployment rate, OECD

Table 18.2 Labour market position of younger people (aged 15-24 years)

\begin{tabular}{lrrrrrr}
\hline & 2010 & 2011 & 2012 & 2013 & 2014 & 2015 \\
\hline Employment & 62.5 & 62.9 & 61.7 & 61.9 & 61.6 & 61.0 \\
Unemployment & 7.2 & 5.9 & 6.1 & 7.0 & 7.7 & 6.4 \\
\hline
\end{tabular}

Source: Employment, Eurostat; Unemployment, Swiss statistical office (2nd quarter)

Non-European migrants are another group that is relatively disadvantaged in the Swiss labour market, with an employment rate lower than that of Swiss nationals and EU/EFTA (European Free Trade Association) migrants. Partly this has to do with the channel through which different migrants arrive in Switzerland. EU/EFTA nationals come most often in order to take up employment, and since the adoption of the agreement on the free movement of workers, their employment rate has increased. It is interesting to note that over the same period of time, the employment rate of Swiss has also increased, though to a smaller extent. Non-European migrants instead come to Switzerland mostly from other channels, often as asylum seekers. This is related to the lower employment rate of this group. It should also be noted that non-European migrants are the only group which has not taken advantage of the expansion of employment since the early 2000; Table 18.3 shows how invariant their employment rates have remained.

The overall poverty rate puts Switzerland in the same category as Germany, with $\mathrm{AROP}^{3}$ rates around $15 \%$. The very high AROP rate reported for

\footnotetext{
${ }^{3}$ AROP, the "at risk of poverty" rate, refers to the percentage of the population living in households with income below $60 \%$ of equivalent disposable income. This definition is used by the EU Commission and has become relatively widely accepted among poverty researchers.
} 
Table 18.3 Employment rates by nationality (aged 15-64 years)

\begin{tabular}{lrrrrrrr}
\hline & 2010 & 2011 & 2012 & 2013 & 2014 & 2015 & 2016 \\
\hline Swiss & 82.5 & 82.9 & 82.6 & 83.3 & 83.7 & 83.7 & 84.9 \\
EU or EFTA & 84.7 & 85.7 & 86.0 & 86.0 & 86.7 & 86.5 & 87.2 \\
Other country & 74.4 & 73.2 & 74.0 & 73.7 & 74.7 & 73.4 & 74.8 \\
\hline
\end{tabular}

Source: Bundesamt fuer Statistik, ESPA, data refer to second trimester

Table 18.4 Poverty statistics (percentages)

\begin{tabular}{llllll}
\hline & 2010 & 2011 & 2012 & 2013 & 2014 \\
\hline At risk of poverty, total & 15.0 & 15.0 & 15.9 & 14.5 & 13.8 \\
At risk of poverty, aged 65 years and over & 27.6 & 28.1 & 29.9 & 29.5 & $25.7^{\text {a }}$ \\
\hline
\end{tabular}

Source: Eurostat (based on SILC data) Data not available for 2015

${ }^{\mathrm{a}}$ Change in series

older people by Eurostat is somewhat misleading, however. Swiss pensioners can choose to receive their second pillar pension as a lump sum, and many do because it is more convenient from a fiscal point of view. As a result, many income-poor seniors are in fact asset-rich. Swiss data therefore suggest that the actual economic situation of elderly people is not as unfavourable as suggested by Eurostat figures. Swiss perceptions are also that the pension system is fairly successful in guaranteed a decent standard of living to retirees - a perception that is clearly at odds with the very high reported AROP rate shown in Table 18.4.

The incidence of poverty can also be evaluated with reference to the proportion of the population that must rely on social assistance. Over the last few years, that proportion has remained constant at around 3\%, but this stability in the percentage is also misleading. In fact, as can be seen in Table 18.5, between 2009 and 2015, a period of good labour market performance, the absolute number of social assistance recipients consistently increased, reflecting an increase in population size due to in-migration.

In fact, the increase in the number of social assistance recipients has been fairly constant since the early 1990s (Bonoli and Champion 2014), even during a recent period when employment was increasing. This indicates that the labour market has become more competitive, possibly because of the free movement of labour agreement with the European 
Table 18.5 Social assistance caseload

\begin{tabular}{llllllll}
\hline & 2009 & 2010 & 2011 & 2012 & 2013 & 2014 & 2015 \\
\hline $\begin{array}{l}\text { Total number of } \\
\text { recipients }\end{array}$ & 230,019 & 231,046 & 236,133 & 250,333 & 257,192 & 261,983 & 265,626 \\
$\begin{array}{l}\text { As a percentage of } \\
\text { the resident } \\
\text { population }\end{array}$ & 3.0 & 3.0 & 3.0 & 3.1 & 3.2 & 3.2 & 3.2 \\
\hline
\end{tabular}

Source: Swiss Federal Statistical Office

Union, and less productive individuals are finding it more difficult to enter and remain in the labour market.

With regard to child poverty, a recent report by the Swiss Federal Statistical Office found that overall, children in Switzerland fare relatively well, particularly in comparison with other European countries. Only the Nordic countries and the Netherlands have indicators of child welfare which are as good or slightly better (FSO 2016, p. 26). Nevertheless, there are some groups which remain of concern, including children living in single-parent households, children living in households with three or more children, and children of non-Swiss parents. In these groups, poverty and deprivation rates are higher than the norm and more worrisome.

Overall, the Swiss social security system seems capable of delivering reasonably good levels of economic security to the resident population. However, the fact that social indicators remain rather favourable does not necessarily constitute proof that the Swiss welfare state is particularly well calibrated to the needs of society. It may well be that the good performance is due more to the country's overall economic competitiveness rather than to its welfare state schemes. In simpler terms, it is relatively easy to build an effective welfare state in a country with a buoyant labour market and a consistently low unemployment rate.

In reality, each of the four main schemes has strengths and weaknesses. In addition, the fragmentation of the system along federalist lines makes internal coordination of, and in, the Swiss social security system difficult.

The Swiss welfare state is a rather diverse construct with some programmes, such as the basic pension scheme, which are highly centralized, and others, such as social assistance, which are extremely decentralized. Between them, one finds schemes that rely on a division of labour between federal and cantonal levels. Unemployment and disability insurance are 
governed by the federal authorities but are implemented at the cantonal level, sometimes with substantial variations from canton to canton. This raises issues about the equality of treatment across cantons, creates difficulties in coordination, and more abstractly, principal-agent problems.

The current trend is to increasingly use quantitative indicators and benchmarking to try to ensure some coherence in how policies are implemented and to try to maximize their efficacy. Federal authorities also use benchmarking in an effort to "control" the cantons, as well as to avoid the potential problems of principal and agent that can emerge if financing and implementation are performed by two different levels of government.

Coordination strategies are pursued through intercantonal associations such as SKOS/CSIAS or other intercantonal bodies, which formally represent the relevant department and offices at the cantonal level. There seems to be an instinctive preference in Switzerland to resolve coordination problems through voluntary agreements between cantons rather than by centralizing systems.

Coordination problems are further compounded by the involvement of private actors in the system. This is most clearly the case in old age pensions, where private occupational pensions have developed into an industry, one with substantial interests at stake. The objectives of such private actors are not always compatible with the social policy goals set by the public authorities, so that substantial coordination work is needed on this front as well.

So though social indicators remain rather favourable, the institutional contours of the Swiss social security system also remain highly fragmented. The result is that public authorities need to invest substantial efforts in coordinating the welfare state system, and the fragmentation may prove a liability in the future.

\subsection{Prospective Thinking}

The Swiss social security system faces challenges like those faced by other European countries. They include:

- Financing the pension system over the longer term

- Containing the rise in the number of benefit recipients

- Improving the effectiveness of re-employment services

- Facilitating the work-life balance particularly for parents of young children 
- Promoting the integration of migrants and their communities

- Enhancing social inclusion

Overall, the Swiss welfare state is relatively well equipped to deal with these challenges, and this task is facilitated by the overall favourable economic situation. Nonetheless, some issues will need to be resolved if the challenges above are to be dealt effectively.

First, though the pension system is regarded as rather efficient, it needs to be made more financially viable for the next few decades. The first pillar pension scheme has been running small deficits for several years, and owing to an ageing population, its financial situation will begin to become critical by around 2030. If no measures are taken, its reserve fund will be used up even before then.

Second, the conversion rate (of $6.8 \%$, see above) applied to the assets of occupational pensions is not sustainable in the current low interest rates/ low returns environment. The result is that a small proportion of current contributions are being used to pay for current benefits instead of being set aside for future pensions. Any extra returns obtained tend to be used to finance current pensions instead of being distributed across the whole pool of insured persons.

The long-term financing of the basic pension and the reduction of the conversion rate for second pillar pensions are thorny political issues. A high-profile reform which tried to deal with both problems without reducing the overall level of benefits was turned down by the voters in September 2017. It is unclear how these issues will be resolved. Pension policy has clearly become an object of political competition among parties, and it is difficult to find a consensus over unpopular measures.

Third, the social security system has been modernized and it now oriented towards the promotion of labour market re-entry. This reflects, at least in part, the "social investment approach" (Hemerijck 2017; Morel et al. 2012). Unemployment and disability insurance provide extensive labour market and rehabilitation programmes for non-working "clients".

However, the same is not true of social assistance. This "last resort" safety net is within the competence of the cantons, and in many cantons, of the municipalities. Here, the turn to activation or social investment has been much more uneven, with some cantons having clearly embraced the new paradigm while others lag behind. This may be one reason why social assistance caseloads keep increasing even in buoyant labour markets and an expanding economy. It will be a challenge in the next few years how the 
activation dimension in social assistance can be reinforced-and how to caseloads from increasing.

Fourth, the Swiss welfare state is highly fragmented, a broad but also a quite specific problem. There is evidence, for example, that cantonal or municipal social assistance programmes and federal social insurance schemes shift "clients" to one another, because there are structural incentives (including those associated with costs) to do so (Bonoli and Champion 2014; Bonoli and Trein 2016).

Finally, as in other countries, a major policy challenge for Switzerland remains improving the work-life balance, especially for families with young children. Switzerland provides only 14 weeks of maternity leave and has no parental leave. In addition, there are simply not enough childcare centres, as one can see from the long waiting lists in many urban areas. Furthermore, the cost of childcare for parents is among the highest of all the Organization for Economic Co-operation and Development (OECD) countries (OECD 2011, p. 150). This situation also results in a very strong social bias against certain migrant communities and low-income families; their access to childcare services is even more limited than for citizens (Bonoli and Vuille 2013; Schlanser 2011). This is unfortunate, because Switzerland is missing out on an important opportunity to promote social inclusion and the integration of migrant families.

\section{REFERENCES}

Bonoli, G. (2007). Switzerland: Development and crisis of a multipillar pension system. In K. M. Anderson, E. M. Immergut, \& I. Schulze (Eds.), Oxford handbook of West European pension politics. Oxford: Oxford University Press.

Bonoli, G., \& Champion, C. (2014). Federalism and welfare to work in Switzerland - The development of active social policies in a fragmented welfare state. Publius the Journal of Federalism, 45(1), 77-98.

Bonoli, G., \& Gay-des-Combes, B. (2003). Evolution de prestations vieillesse dans le long terme: une simulation prospective de la couverture retraite à l'horizon 2040. Bern: Office fédéral des assurances sociales, Rapport de recherche No. $3 / 03$.

Bonoli, G., \& Trein, P. (2016). Cost-shifting in multitiered welfare states: Responding to rising welfare caseloads in Germany and Switzerland. Publius: The Journal of Federalism, 46(4), 596-622.

Bonoli, G., \& Trein, P. (2017). ESPN country profile: Switzerland. Brussels: European Commission. 
Bonoli, G., \& Vuille, S. (2013). L'accueil de jour des enfants dans le Canton de Vaud. Lausanne: Fondation pour l'Accueil de Jour de Enfants (FAJE), Research report.

Duell, N., Tergeist, P., Bazant, U., \& Cimper, S. (2010). Activation policies in Switzerland. Paris: OECD Social Employment and Migration Working Papers. FSO (Federal Statistical Office). (2016). Pauvreté et privations matérielles des enfants. Neuchatel: Federal Statistical Office.

Hemerijck, A. (Ed.). (2017). Social investment and its critics. Oxford: Oxford University Press.

Leimgruber, M. (2008). Solidarity without the state? Business and the shaping of the Swiss welfare state, 1890-2000. Cambridge: Cambridge University Press.

Morel, N., Palier, B., \& Palme, J. (Eds.). (2012). Towards a social investment welfare state?: Ideas, policies and challenges. Bristol: The Policy Press.

OECD (Organisation for Economic Co-operation and Development). (2011). Doing better for families. Paris: OECD.

Schlanser, R. (2011). Qui utilise les crèches en Suisse? Logiques sociales du recours aux structures d'accueil collectif pour la petite enfance. Lausanne: IDHEAP, Cahier No. 264.

SKOS (Schweizerische Konferenz für Sozialhilfe). (2015). SKOS-Richtlinien (in German, French and Italian). Berne: SKOS.

Vontobel, W. (2000, December 1). Die Saülen-Scheinheiligen: Pech hat, wer in einem Kleinbetieb arbeitet. CASH.

Open Access This chapter is licensed under the terms of the Creative Commons Attribution 4.0 International License (http://creativecommons.org/licenses/ by $/ 4.0 /$ ), which permits use, sharing, adaptation, distribution and reproduction in any medium or format, as long as you give appropriate credit to the original author(s) and the source, provide a link to the Creative Commons license and indicate if changes were made.

The images or other third party material in this chapter are included in the chapter's Creative Commons license, unless indicated otherwise in a credit line to the material. If material is not included in the chapter's Creative Commons license and your intended use is not permitted by statutory regulation or exceeds the permitted use, you will need to obtain permission directly from the copyright holder.

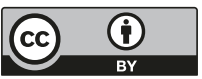

